\title{
When Leaders Talk to Leaders
}

\section{Quand les leaders sadressent aux leaders}

\author{
by ANTON HART \\ Publisher, Healthcare Policy
}

\begin{abstract}
Presentations by three Canadian executives who influence healthcare policy and practice were reviewed to identify the kinds of sources these leaders use to draw their conclusions. All three speakers examined policies, practices and outcomes. Presentations were selected to cover activities in three provinces in three different calendar years, to avoid duplication or undue influence of a particular event or release of information. All three speakers drew heavily on data from government sources, especially the Canadian Institute for Health Information (CIHI).
\end{abstract}

\section{Résumé}

Les présentations de trois dirigeants canadiens qui ont de l'influence sur les politiques et pratiques en matière de soins de santé sont passées en revue pour définir le genre de sources sur lesquelles ces leaders se fondent pour tirer leurs conclusions. Ils se penchent tous les trois sur les politiques, les pratiques et les résultats. Les présentations sélectionnées couvrent des activités ayant eu lieu dans trois provinces différentes et au cours de trois années civiles différentes de sorte à éviter qu'un événement ou communiqué d'information particulier soit en double ou dominant. Les données 
utilisées par ces trois conférenciers sont tirées largement de diverses sources gouvernementales, dont l'Institut canadien d'information sur la santé (ICIS).

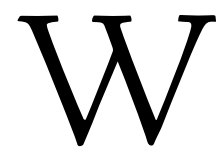

HEN LEADERS IN HEALTHCARE PRACTICE, RESEARCH, EDUCATION AND administration come to listen and learn about policy and best practices, what resources do their mentors of the moment use? This summary identifies source materials used by three leaders in their respective health services domains in presentations made to an assembly of peers. All three - Dr. Penny Ballem, BC Deputy Minister of Health; Dr. Michael Guerriere, healthcare strategist and Chair of Ryerson University in Toronto; and Ms. Sheila Weatherill, CEO of Capital Health, Edmonton - speak persuasively and often. All influence people, policy and practice.

This review is intended as only one measure of the issues that these decisionmakers believe are important, and of the data that influence their views. Since the presenters have attached value to this information, it is fair to assume that they believe it can contribute to solutions. It does not necessarily reflect the priorities of the researchers who compiled the data but, in fact, presents an opportunity for researchers to see how and when their work is or could be considered.

The purpose of this summary is to identify the bases for these leaders' views and decisions. On reflecting on Dr. Robert Evan's column in this journal, this also offers an opportunity to assess possible influences by strong economic interests that might block or distort the messages from research, or encourage the substitution of self-serving myths in place of data. ${ }^{1}$ That should prove to be an interesting conversation for a future issue.

\section{Dr. Penny Ballem, Deputy Minister of Health, British Columbia}

Dr. Ballem is the longest-serving deputy minister of health in Canada in office today; she is also on the board of the Canadian Institute for Health Information (CIHI). Previously, she was a Vice-President of the Children's and Women's Health Centre and a Clinical Professor at the University of British Columbia's Faculty of Medicine.

A woman who wears her disposition on her sleeve. Dr. Ballem was invited (by the publishers of this journal) to speak to a crowd of 200 CEOs, directors and frontline managers on any topic she wished. Her day started typically at about six in the morning with media calls about the latest pressing issue - one that (she shared with us) would surely throw her schedule into complete disarray. The day before she addressed a healthcare research group, had a new budget to contend with and was preparing her premier for a fact-finding trip to Europe. Yet she spoke for 40 minutes with clarity, 
passion and humour about health status in British Columbia. She shared comparisons, challenges, budgets and priorities for change including access, waiting times, quality of care, sustainability and affordability. That's a schedule and a persona to consider when planning knowledge transfer.

- Presentation title: Advancing Healthcare in British Columbia ${ }^{2}$

- Date presented: February 22, 2006 in Vancouver

- Listed sources: $\mathrm{BC}$ government sources ${ }^{3}$ (15 references in total, including Medical Services Plan [2 references]; Ministry of Community, Aboriginal and Women's Services; Ministry of Health [7 references]; Ministry of Management Services; BC Stats Population Data [2 references]; Vital Statistics Agency [2 references]); CIHI (4 references); Canadian Medical Association Journal (2 references); Cancer Advocacy Coalition of Canada Report Card; Centre for Health Services and Policy; Conference Board of Canada; Health Council of Canada; OECD Health Project (2 references); Statistics Canada Canadian Community Health Survey; Vancouver General Hospital ICU Report

\section{Dr. Michael Guerriere, Managing Partner, The Courtyard Group}

Dr. Guerriere holds a business degree as well as a degree in medicine. He has served at both St. Michael's Hospital and the University Health Network, most recently as Executive Vice-President, and has sat on the boards of CIHI and Infoway. With considerable expertise in health informatics and healthcare efficiencies, Dr. Guerriere holds strong and well-thought-out opinions: he insists that published research, ideas and policies have value to the reader and reflect real data that is actionable. He is prepared to take risks if they are carefully calculated and measured. Healthcare experts, CEOs and ministers across the country listen to him. He is not without a story or two at the beginning of his presentations but they will apply to the topic and settle the audience in for the next 40 minutes. He has your attention. This too was a presentation made to senior administrators, policy makers and researchers at a Longwoods breakfast event.

- Presentation title: Annual Review in IM/IT in Healthcare: The Unvarnished Version ${ }^{4}$

- Date presented: February 21, 2005 in Toronto

- Listed sources: Annals of Internal Medicine (2 references); Canada Health Infoway; CIHI (5 references); Canadian Medical Association Journal; Capital Health, Edmonton; Danish Health Data Network; The Gartner Group; The Globe and Mail; Eli Lily, Inc., Hospital Pharmacy in Canada Survey; Massachusetts Technology Collaborative; Medcom; New England Journal of Medicine; Statistics 
Canada (3 references); OECD (3 references); Rand Corporation; US Institute of Medicine; US National Highway Transportation Safety Administration

\section{Sheila Weatherill, CEO, Capital Health, Edmonton}

Capital Health is one of the largest integrated health regions in Canada (serving a population of 1.6 million, with some 20,000 employees) and, according to CIHI and Maclean's magazine, it is the country's best. A leader among leaders, Ms. Weatherill heads an organization that is developing a strong national mandate. Adept at consensus building, she typifies balance. She has led the Association of Canadian Academic Healthcare Organizations, sits on numerous other boards, including the Conference Board of Canada and the Institute for Health Economics, and is currently Vice-Chair of CIHI. Ms. Weatherill has also lent her voice to local boards, including the YMCA. When she made the presentation reviewed here to a full house of leaders in healthcare practice, research, education and administration, Ms. Weatherill was well briefed, sharp in her comments and thoughtful in her responses. Yet she too had come from a very full schedule in Edmonton and arrived in Toronto on the "red-eye" demonstrating that promises are made and commitments are kept both at home and on the road.

- Presentation title: Improving Productivity: An Alberta Perspective on Health Reform ${ }^{5}$

- Date presented: October 19, 2004 in Toronto

- Listed sources: Canadian Cardiovascular Outcomes Research Team; CIHI (6 references); Canadian Journal of Neurological Sciences; Capital Health (extensive references, including data from netCare, Capital's electronic health record); Conference Board of Canada; Environics; Maclean's; Ottawa Health Research Institute; Southam Medical Database; Statistics Canada

\section{Summary}

All three presentations made heavy use of data from provincial and other government sources, especially the Canadian Institute for Health Information. Given the influence that these three senior executives wield among leaders in healthcare practice, research, education and administration, researchers who have something to share with them would do well to take note of their personalities, their style, their focus on issues and their resources. In future issues we can explore their use of these resources and the basis for their policy and practice decisions. 


\section{NOTES}

1. See Dr. Bob Evans's commentary, "Kafka, New Orleans, the OARs and the KT Boundary," Healthcare Policy 1(2): 14-20.

2. See <http://longwoods.com/website/jobsite/BC06BallemBC.pdf>.

3. Dr. Ballem also presented the following list of reports and publications that she is expected to read:

Annual Report on Health Authority Performance Agreement

Auditor General of BC Reports

Budget Transparency and Accountability Act

Canadian Institute for Health Information Reports

Conference Board of Canada Reports

First Ministers Agreements Reports

Government of BC Progress Board Report

Health Authority Performance Agreements

Ministry Annual Report on Service Plans

Ministry Service Plans

National Health Council Reports

National Performance Indicator Reports

Provincial Health Officer Reports

Statistics Canada Annual Access Survey

Vital Statistics

4. See $<$ http://longwoods.com/pages.php?pageid $=70>$.

5. See <http://www.longwoods.com/website/events/breakfast/BC04Weatherill/index.html>.

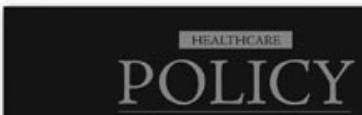

Politiques de Santé

\section{자}

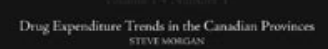

Public Drug Plas Conerage for Children across Canada

Interactioas between Rescarthers and

Interactoar between Rescarthess ant

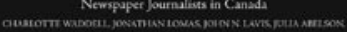

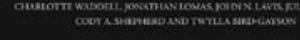

The State of Acadenic Health Palicy Reseanch Centres in Canats

C.

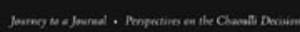

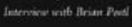

$\Theta$

\section{Research. Evidence. Dissemination.}

